\title{
Dialogues of root-colonizing biocontrol pseudomonads
}

\author{
Christophe Dubuis · Christoph Keel · \\ Dieter Haas
}

Received: 21 December 2006/Accepted: 26 April 2007/Published online: 5 June 2007

(c) KNPV 2007

\begin{abstract}
Among biocontrol agents that are able to suppress root diseases caused by fungal pathogens, root-colonizing fluorescent pseudomonads have received particular attention because many strains of these bacteria trigger systemic resistance in host plants and produce antifungal compounds and exoenzymes. In general, the expression of these plantbeneficial traits is regulated by autoinduction mechanisms and may occur on roots when the pseudomonads form microcolonies. Three major classes of antibiotic compounds reviewed here in detail $(2,4-$ diacetylphloroglucinol, pyoluteorin and various phenazine compounds) are all produced under cell population density-dependent autoinduction control acting at transcriptional and post-transcriptional levels. This regulation can either be reinforced or attenuated by a variety of chemical signals emanating from the pseudomonads themselves, other microorganisms or root exudates. Signals stimulating biocontrol factor expression via the Gac/Rsm signal transduction pathway in the biocontrol strain Pseudomonas fluorescens $\mathrm{CHA} 0$ are synthesized by many different plant-associated bacteria, warranting a more detailed investigation in the future.
\end{abstract}

C. Dubuis · C. Keel · D. Haas $(\bowtie)$

Département de Microbiologie Fondamentale, Université de Lausanne, Lausanne 1015, Switzerland

e-mail: Dieter.Haas@unil.ch
Keywords Antibiotic compounds - Biocontrol . GacS/GacA · Quorum sensing · Pseudomonas . Rhizosphere
Abbreviations
AHL $\quad N$-acyl-homoserine lactone
AI-2 Autoinducer 2
DAPG 2,4-Diacetylphloroglucinol
HCN Hydrogen cyanide
IAA Indole-3-acetic acid
PCA Phenazine-1-carboxylic acid
PLT Pyoluteorin
PQS Pseudomonas quinolone signal
QS Quorum sensing

\section{Introduction}

Probably all free-living bacteria communicate with one another by synthesizing, secreting and sensing signal molecules, which diffuse in the environment and are detected by specific cellular receptors. The main tasks of these signals are to coordinate metabolic activities and developmental processes in bacterial populations. In general, the higher the cell population densities are in growing cells, the more important signalling becomes. This relationship is known as quorum sensing (QS) and it is assumed that signalling enables the producer bacteria to assess their population densities (Fuqua et al. 1994). To some extent, this is certainly an important aspect. In 
many cases, signals amplify their own biosynthesis. Thus, in growing populations, this positive feedback loop results in autoinduction and for this reason, such QS signals are also termed autoinducers (Nealson 1977). However, the physiological condition of the cells and many environmental factors can modulate the concentration of the QS signals and hence the cellular response (Lazdunski et al. 2004; Hense et al. 2007).

In the rhizosphere, bacterial populations preferentially form microcolonies in areas that are particularly rich in root exudates (Bais et al. 2006). Here, the production of QS signals can readily be detected by signal-specific biosensors (Pierson et al. 1998; Steidle et al. 2001). The calling distance, i.e. the range of cell-cell communication via chemical signals, has been experimentally determined on plant roots and estimated to be of the order of $5 \mu \mathrm{m}$, but under favourable conditions, e.g. at root tips or root hair junctions, it can extend beyond $50 \mu \mathrm{m}$ (Gantner et al. 2006). In many rhizobacteria, QS mechanisms induce the synthesis of antimicrobial secondary metabolites and extracellular lytic enzymes that are inhibitory to other bacteria, fungi, protozoa, and nematodes (Haas et al. 2000; Haas and Défago 2005; Siddiqui et al. 2005; Juhas et al. 2005; Jousset et al. 2006). We have argued elsewhere that a primary function of these antimicrobial factors is to protect the producer microcolonies from invasion by other inhabitants of the rhizosphere and hence to preserve the integrity of the producer in its ecological niche on plant roots (Haas and Keel 2003). The measured calling distances of QS signals correspond well to microcolony dimensions. When antibiotic-producing rhizobacteria antagonize the proliferation of rootpathogenic fungi on roots and when, in addition, the defence reactions of the host plant are stimulated, a significant biocontrol effect can result: the plant becomes less susceptible to disease caused by pathogenic fungi. In this review, we will discuss some signal transduction pathways that positively control the expression of biocontrol factors in rootcolonizing soil bacteria belonging to the group of fluorescent pseudomonads. These bacteria have been studied in considerable detail for their biocontrol properties and their signalling pathways (MoënneLoccoz and Défago 2004; Juhas et al. 2005; Haas and Défago 2005).

\section{Signals and nutrients}

Signals that are engaged in cell-cell communication of microorganisms meet several criteria: they are produced during a particular growth phase and in response to environmental conditions, they accumulate in the extracellular medium, they interact specifically with cellular receptors and, above a threshold, they trigger expression of a set of genes. However, all these criteria can also be fulfilled by nutrients which are degraded by microorganisms through inducible pathways. For instance, glucose, a sugar present in the rhizosphere (Lugtenberg and Bloemberg 2004), is converted to gluconate by glucose oxidase in fluorescent pseudomonads (Quay et al. 1972). The diffusible product gluconate, which acts as an antifungal agent (Kaur et al. 2006), induces the enzymes of the EntnerDoudoroff pathway leading to the degradation of gluconate and glucose (Quay et al. 1972). Should gluconate be considered a signal? Some authors indeed do not discriminate between rhizosphere signals that primarily serve as nutrients and those that specifically trigger gene expression without having nutritional value (Somers et al. 2004). Other authors emphasize that signals used in cell-cell communication typically regulate gene expression beyond the physiological changes required to metabolize or to inactivate the signals and that, therefore, signals should be distinguished from nutrients (Winzer et al. 2002). In the following, we will adopt the latter view and we will not discuss how nutrients present in exudates chemotactically attract soil bacteria and how these bacteria subsequently attach to root surfaces and form microcolonies. These processes have been reviewed elsewhere (Somers et al. 2004; Lugtenberg and Bloemberg 2004).

Signals that influence the expression of biocontrol traits in pseudomonads can emanate from the biocontrol bacteria themselves, from other soil bacteria or fungi, or from host plants (Fig. 1). Like any biological molecules, signals can be degraded, either by the producing organisms, which thereby avoid an overshooting response (Huang et al. 2006a; Wang et al. 2006), or by other organisms which cause interference of signalling pathways (Zhang and Dong 2004; Xavier and Bassler 2005; González and Keshavan 2006). Signals can have stimulating or inhibitory effects, with repercussion on transcriptional or translational control of biocontrol gene expression. 


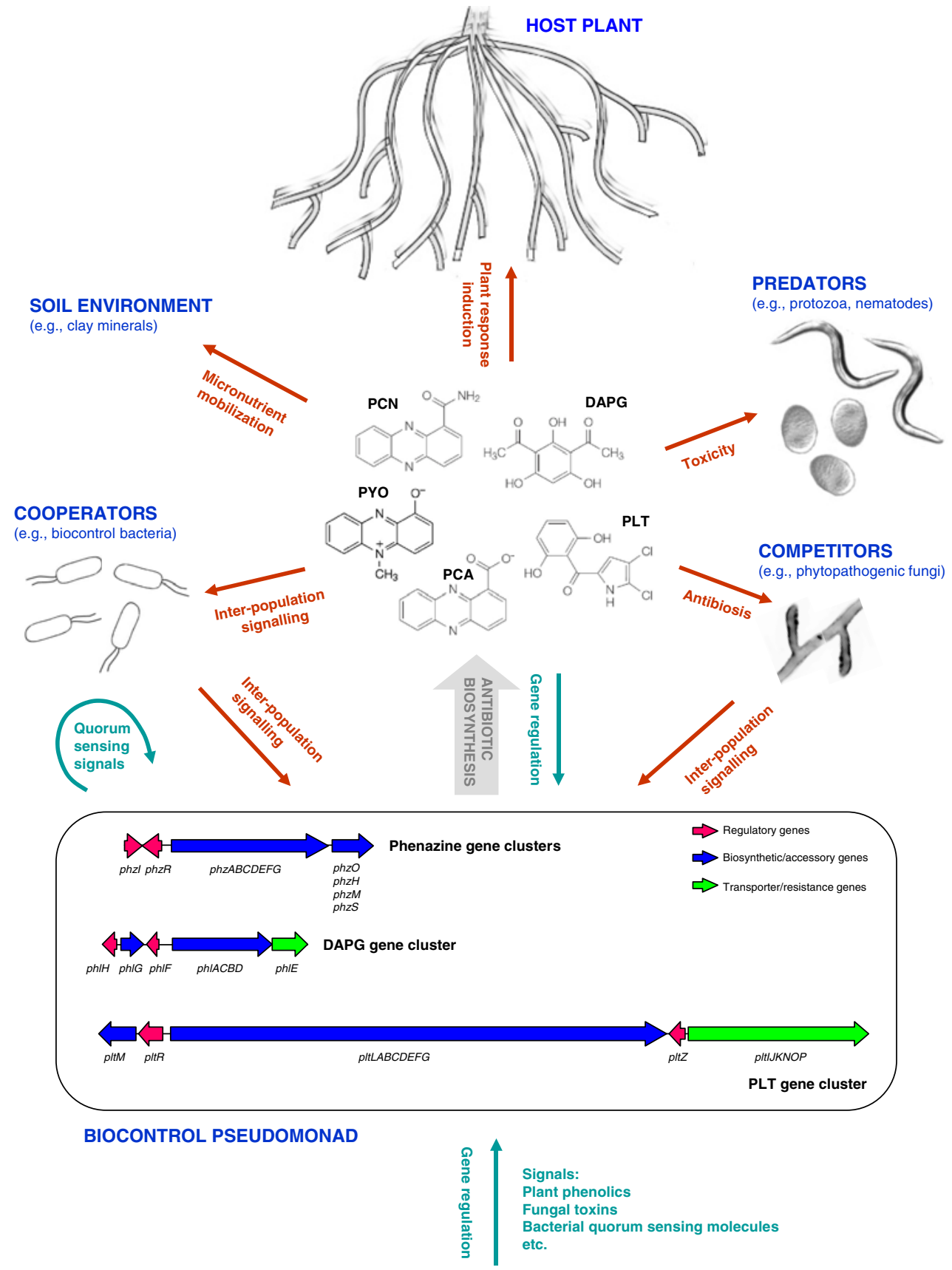

Fig. 1 Overview of interactions between biocontrol strains, plants, pathogens, predators, co-operators, and soil. The antibiotics (phenazines, DAPG, PLT) produced by the biocontrol strains play a central role between all the elements of the complex network of interactions. The organization of the $p h z$, phl and plt biosynthetic genes in fluorescent pseudomonads is according to Mavrodi et al. (2006); Bangera and Thomashow (1999); Schnider-Keel et al. (2000); and Brodhagen et al. (2005). Red arrows designate interactions, green arrows designate transcriptional gene regulation 


\section{Signals affecting biocontrol factor expression at a transcriptional level}

Control of root diseases by biocontrol pseudomonads involves a blend of complementary mechanisms, the most prominent being antibiosis towards plant pathogens, degradation of virulence factors produced by pathogens and induction of defence mechanisms in host plants. Efficient competition for colonization sites and micro- and macro-nutrients in the rhizosphere is an important prerequisite for effective biocontrol (van Loon et al. 1998; Lugtenberg et al. 2001; Compant et al. 2005; Haas and Défago 2005). Root-colonizing plant-beneficial pseudomonads release a remarkable diversity of metabolites with antibiotic activity. There is compelling experimental evidence from genetic analyses involving antibioticnegative mutants and from detection of antibiotic production in the rhizosphere by analytical and reporter gene techniques that these compounds are important for biocontrol activity (Raaijmakers et al. 2002; Haas and Keel 2003; Haas and Défago 2005). Furthermore, it has been established that populations of antibiotic-producing, rhizosphere-associated pseudomonads are key biological components in natural soils that are suppressive to major root diseases such as take-all of wheat and black root of tobacco (Keel et al. 1996; Weller et al. 2002; Ramette et al. 2003; de Souza et al. 2003a; Weller et al. 2007).

Among the antimicrobial compounds released by plant-beneficial pseudomonads, 2,4-diacetylphloroglucinol (DAPG), pyoluteorin (PLT), phenazines, hydrogen cyanide $(\mathrm{HCN})$, and cyclic lipopeptides (e.g., viscosinamide, amphisin, putisolvin) have received particular attention for their major contribution to biocontrol of root diseases that are caused by agronomically important fungal and oomycete pathogens including Gaeumannomyces, Thielaviopsis, Fusarium, and Pythium species (Haas and Keel 2003; Chin-A-Woeng et al. 2003; Andersen et al. 2003; Kuiper et al. 2004; Mavrodi et al. 2006; Raaijmakers et al. 2006; Rezzonico et al. 2007; Weller et al. 2007). Most effective biocontrol pseudomonads produce at least one of the above-mentioned diffusible or volatile antibiotics and some strains, e.g. Pseudomonas fluorescens strains CHA0 and Pf-5, produce multiple antibiotics. In general, these antibiotics have broad-spectrum toxic activity against fungi, bacteria, protozoa, nematodes, and sometimes also against plants or even viruses (Raaijmakers et al. 2002, 2006; Haas and Keel 2003; Jousset et al. 2006). However, for DAPG and PLT the precise modes of action are largely unknown. Phenazines being redox-active antibiotics are thought to harm phytopathogenic fungi by generation of reactive oxygen species (Chin-A-Woeng et al. 2003; Mavrodi et al. 2006; Price-Whelan et al. 2006). HCN is an inhibitor of metalloenzymes, in particular of most terminal oxidases (Blumer and Haas 2000). Cyclic lipopeptides are surfactants promoting surface motility of the producer organism; at high concentrations, they are detrimental to the integrity of phospholipid membranes in various organisms (Raaijmakers et al. 2006).

Some of the antibiotic metabolites have remarkably diverse functions, besides their toxic activity (Fig. 1). DAPG, PLT, and phenazines can function as signal molecules that affect gene expression not only in the producer bacteria, but also in other organisms (Schnider-Keel et al. 2000; Maurhofer et al. 2004; Brodhagen et al. 2004; Baehler et al. 2005; Dietrich et al. 2006; Price-Whelan et al. 2006). DAPG has been described as an inducer of systemic plant resistance (Iavicoli et al. 2003; Weller et al. 2007) and as a stimulant of amino acid exudation from roots (Phillips et al. 2004). Phenazines, in their reduced form, might enable the producing bacteria to mobilize micronutrients such as iron $\left(\mathrm{Fe}^{3+}\right)$ from the rhizosphere environment (Hernandez et al. 2004; PriceWhelan et al. 2006). In the following, we will highlight some examples of signal perception and exchange involving transcriptional control mechanisms, with a focus on the biosyntheses of DAPG, PLT, and phenazines (Fig. 1).

\section{DAPG and PLT as signals}

DAPG has been shown to be particularly important in the suppression of root diseases caused by Thielaviopis basicola (Keel et al. 1990), Pythium ultimum (Fenton et al. 1992; Baehler et al. 2006) and Gaeumannomyces graminis (Keel et al. 1992). The DAPG biosynthetic locus has been identified and analysed in some detail in P. fluorescens strains Q287, CHA0, and F113 (Bangera and Thomashow 1999; Schnider-Keel et al. 2000; Delany et al. 2000). The DAPG locus comprises the biosynthetic genes phlACBD; phlD encodes a type III polyketide 
synthase catalysing the synthesis of phloroglucinol from malonyl-CoA and phlACB encodes enzymes that presumably are required for the subsequent acetylation reactions to mono-acetylphloroglucinol and DAPG (Achkar et al. 2005; Zha et al. 2006). The phlE gene located downstream of the phlACBD cluster codes for a putative transport/resistance protein (Bangera and Thomashow 1999; Abbas et al. 2004). The $p h l F$, $p h l G$, and $p h l H$ genes located upstream of the biosynthetic genes encode, respectively, a pathway-specific transcriptional repressor belonging to the TetR family, a hydrolase that specifically degrades DAPG to less toxic monoacetylphloroglucinol, and a second TetR-type transcriptional regulator that activates the expression of the phlACBD genes and negatively controls phlG (Bangera and Thomashow 1999; Schnider-Keel et al. 2000; Delany et al. 2000; Abbas et al. 2004; Bottiglieri and Keel 2006). Pathway-specific control in strains CHA0 and F113 is brought about by the PhlF protein which represses the expression of the phlACBD operon by binding to two conserved operator sites in the phlA leader region (SchniderKeel et al. 2000; Delany et al. 2000; Haas and Keel 2003; Abbas et al. 2004; D. Haas and C. GigotBonnefoy, unpublished results). DAPG itself acts as the derepressing signal by dissociating the repressor PhlF from the phlA promoter, thereby acting as an autoinducer of its own biosynthesis (Schnider-Keel et al. 2000; Abbas et al. 2004). PhlH, the second pathway-associated transcriptional regulator, is postulated to antagonize the repressive effect of PhlF, but the precise mechanism remains to be determined (Haas and Keel 2003).

Pyoluteorin is another important antimicrobial metabolite that is produced by some Pseudomonas strains and that contributes in particular to the suppression of root diseases caused by the oomycete P. ultimum (Howell and Stipanovic 1980; Maurhofer et al. 1992, 1994). The PLT biosynthetic locus has been identified in P. fluorescens Pf-5 (Kraus and Loper 1995; Nowak-Thompson et al. 1999), in P. fluorescens CHA0 (Péchy-Tarr et al. 2005) and in Pseudomonas sp. M18, which appears to belong to P. aeruginosa ( $\mathrm{Ge}$ et al. 2004). The biosynthetic locus comprises the pltLABCDEFG and pltM genes; $p l t B$ and pltC encode polyketide synthases with core functions in PLT biosynthesis (Nowak-Thompson et al. 1999). Pathway-specific positive control of PLT biosynthetic gene expression in strains $\mathrm{CHA} 0$ and Pf5 is brought about by a LysR-type transcriptional regulator encoded by the divergently transcribed pltR gene (Nowak-Thompson et al. 1999; M. Bottiglieri and C. Keel, unpublished data). PLT induces its own biosynthesis via an autoinduction mechanism similar to that described for DAPG (Brodhagen et al. 2004; Baehler et al. 2005) and there is some experimental evidence that the transcriptional activator PltR may mediate this mechanism (M. Bottiglieri and C. Keel, unpublished data). Recently, a second regulatory gene, pltZ, linked to the PLT biosynthetic locus has been identified in strain M18 (Huang et al. 2004) and P. fluorescens strain Pf-5 (Brodhagen et al. 2005). This gene encodes a TetR-type transcriptional repressor of PLT gene expression (Huang et al. 2004) and is located upstream of a genomic region (pltHIJKNO in strain M18 and pltIJKNOP in strain Pf-5) encoding an ABC-type transport apparatus for PLT and accessory membrane-bound proteins (Brodhagen et al. 2005; Huang et al. 2006b). Exogenous PLT induces the expression of both the PLT biosynthetic and transport operons, suggesting that PLT production and export are coordinated (Brodhagen et al. 2005; Huang et al. 2006a, b).

In $P$. fluorescens strains $\mathrm{CHA} 0$ and $\mathrm{Pf}-5$, a mechanism of molecular cross-talk between the DAPG and PLT biosynthetic pathways has been identified that enables the bacteria to maintain production of these key antibiotics at balanced levels. In this molecular balance, DAPG and PLT act as signalling molecules inducing the expression of their own biosynthetic genes while strongly repressing the expression of the biosynthetic genes of the other antibiotic (Schnider-Keel et al. 2000; Brodhagen et al. 2004; Baehler et al. 2005, 2006). The pathwayspecific transcriptional regulators $\mathrm{PhlF}$ and PltR appear to function as receptors of these signals. However, the underlying molecular mechanisms still need to be substantiated. The housekeeping sigma factor RpoD, the alternative sigma factors RpoS, RpoN and RpoE (Schnider et al. 1995; Sarniguet et al. 1995; Johansen et al. 2002; Haas and Keel 2003; Péchy-Tarr et al. 2005), Lon protease (Whistler et al. 2000), and the H-NS-like proteins MvaT and MvaV (Baehler et al. 2006) influence the DAPG/PLT balance. In the rhizosphere environment, these global transcriptional regulators might allow the bacteria to coordinate antibiotic production with other cellular 
functions, such as nutrition acquisition and response to environmental stress.

As exogenous signals, DAPG and PLT mediate both intra- and interpopulation communication. In the genetically distinct biocontrol strains CHA0 and Q287 , DAPG produced by either strain on wheat roots is perceived as a positive signal boosting in situ expression of $p h l$ genes in the other strain (Maurhofer et al. 2004). Similarly, PLT produced by P. fluorescens Pf-5 acts as a signal activating plt gene expression in a PLT-negative derivative of Pf-5 in the rhizosphere of cucumber (Brodhagen et al. 2004). Salicylate, a metabolite produced by strain CHA0, numerous other pseudomonads and plants, strongly represses the production of DAPG and PLT and the expression levels of the corresponding biosynthetic genes (Schnider-Keel et al. 2000; Baehler et al. 2005). It is noteworthy that QS molecules of the $N$ acyl-homoserine lactone (AHL) type, which are synthesized by some DAPG producers such as P. fluorescens F113 (Laue et al. 2000) and 2P24 (Wei and Zhang 2006), do not contribute to the regulation of antibiotic biosynthesis in these bacteria, although AHLs function as key signals in cell-density dependent regulation of phenazine antibiotic production in other biocontrol pseudomonads (see below).

Whereas pathogenic fungi are major targets of biocontrol pseudomonads, only few examples of specific signalling interactions between these organisms have been documented. Fusaric acid, a toxin and pathogenicity factor of the root pathogen Fusarium oxysporum, is probably the most prominent example of a fungal compound that interferes with bacterial expression of a biocontrol trait. Fusaric acid strongly represses DAPG production in P. fluorescens CHA0 (Duffy and Défago 1997; Schnider-Keel et al. 2000; Notz et al. 2002). This repression may ultimately result in failure of the bacterium to suppress the root disease caused by the fungus (Duffy and Défago 1997; Duffy et al. 2004). An example of positive signalling is the stimulation of DAPG gene expression in strain CHA0 by unidentified signals from culture filtrates and volatiles of the biocontrol fungus Trichoderma atroviride (Lutz et al. 2004). Several fungal pathogens including Gaeumannomyces, Pythium, and Fusarium cope with DAPG by detoxifying it or by developing other mechanisms of resistance to it (Mazzola et al. 1995; de Souza et al. 2003b; Duffy et al. 2003; Schouten et al. 2004).
Little is known about plant signals affecting the expression of DAPG and PLT biosynthetic genes in $P$. fluorescens. Clearly, the plant species has an important role in determining the extent of disease suppression provided by $P$. fluorescens strain CHA0, suggesting that signals present in root exudates may modulate the production of biocontrol factors (Maurhofer et al. 1994, 1995; Schmidli-Sacherer et al. 1997). For instance, phl gene expression in strain CHA0 is consistently enhanced in the rhizosphere of cucumber, wheat and maize when Pythium infests the roots (Notz et al. 2001). Since neither the fungus itself nor its culture filtrates stimulate DAPG expression in vitro, increased $p h l$ gene expression is presumably due to alterations in root exudates caused by pathogen attack (Notz et al. 2001; Maurhofer et al. 2002). Furthermore, the phl genes are more strongly expressed on wheat and maize roots than on cucumber and bean roots, pointing to differences in root exudate composition between these monocotyledonous and dicotyledonous plants (Notz et al. 2001). However, the signals involved are largely unknown. Possible candidates are phenolic metabolites that are released by the plants as root exudates or as cell wall degradation products. Phenolic compounds have a number of ecological functions, e.g. as growth inhibitors of other plant species, as antimicrobial agents, or as specific signals guiding interactions between plants and rhizobia or Agrobacterium spp. (Siqueira et al. 1991; Phillips and Kapulnik 1995; Hirsch et al. 2004; Bais et al. 2006). Among several compounds of plant origin, indole-3-acetic acid (IAA) stimulates phl gene expression, resorcinol represses plt gene expression and salicylate downregulates the expression of both phl and plt genes in strain CHA0 (Schnider-Keel et al. 2000; Baehler et al. 2005; de Werra et al. 2006).

Phenazines and AHLs as signals

Phenazine compounds are coloured heterocycles derived from chorismate. They are synthesized by Gram-negative and -positive bacteria. Phenazine-1carboxylic acid (PCA) is the primary product of a set of enzymes encoded by the phzABCDEFG operon in P. fluorescens 2-79, P. chlororaphis PCL1391, $P$. aeruginosa PAO and $P$. aureofaciens 30-84 (although in the last organism a different nomenclature is used for the phz operon) (Pierson et al. 1995; Mavrodi et al. 1998, 2006; McDonald et al. 2001). 
Modification reactions lead from PCA to phenazine1-carboxamide (with $p h z H$ ), 2-hydroxyphenazine-1carboxylic acid (with $\mathrm{phz} O$ ), 1-hydroxyphenazine (with $p h z S$ ) or pyocyanine (=1-hydroxy-5-methylphenazinium betaine, with $p h z M$ and $p h z S$ ) (Chin-AWoeng et al. 2001a; Delaney et al. 2001; Mavrodi et al. 2001; Parsons et al. 2007). The first demonstration of PCA being a biocontrol determinant came from a study on the suppression of take-all by P. fluorescens 2-79 (Thomashow and Weller 1988); take-all is an important disease of wheat and barley caused by $G$. graminis var. tritici (Ggt). Both phenazine-1-carboxamide and 2-hydroxyphenazine1-carboxylic acid, which have stronger antifungal activity against Fusarium spp. and Ggt than has PCA, are particularly important for biocontrol activity of P. chlororaphis PCL1391 and P. aureofaciens 30-84, respectively (Chin-A-Woeng et al. 2001a; Delaney et al. 2001). A combination of PCA and DAPG produced by a genetically engineered derivative of P. fluorescens Q8r1-96 has proved effective against Rhizoctonia root rot of wheat (Huang et al. 2003). We note in passing that certain strains of $P$. aerugin$o s a$, while opportunistic animal and human pathogens, are well adapted to the rhizosphere (Berg et al. 2005) where they can display biocontrol properties (Troxler et al. 1997; Ge et al. 2004) and stimulate induced systemic resistance (Audenaert et al. 2002). In the root-colonizing biocontrol strain $P$. aeruginosa 7NSK2, a combination of pyocyanine and the iron chelator pyochelin induces systemic resistance against the leaf pathogens Botrytis cinerea on tomato and Magnaporte grisea on rice (Audenaert et al. 2002; de Vleesschauwer et al. 2006).

At the transcriptional level, phenazine biosynthesis is controlled by the PhzR-PhzI quorum sensing system. PhzR is a transcriptional activator of the phz operons in P. fluorescens 2-79, P. chlororaphis PCL1391 and $P$. aureofaciens 30-84 and PhzI is an autoinducer synthase producing mostly $N$-(3-hydroxy-hexanoyl)-homoserine lactone (in strain 2-79) and $N$-hexanoyl-homoserine lactone (in the other two strains). These AHLs activate PhzR (Wood and Pierson 1996; Chancey et al. 1999; Chin-A-Woeng et al. 2001b; Khan et al. 2005). Additional regulators of phenazine production have been identified, e.g. RpeA, a repressor of phenazine production in $P$. $a u$ reofaciens 30-84 (Whistler and Pierson 2003), and Pip, which activates phenazine-1-carboxamide pro- duction in $P$. chlororaphis PCL1391, together with the stress and stationary phase sigma factor RpoS (Girard et al. 2006). In P. aeruginosa, QS regulation of secondary metabolism including phenazine biosynthesis is highly complex, involving a hierarchically organized system with two autoinducers, i.e. $\mathrm{N}$ (3-oxododecanoyl)-homoserine lactone (the reaction product of the LasI enzyme and principal activator of the LasR transcription factor) and $\mathrm{N}$-butanoyl-homoserine lactone (the reaction product of the RhlI enzyme and principal activator of the RhlR transcription factor), and the Pseudomonas quinolone signal (PQS) (Lazdunski et al. 2004; Juhas et al. 2005; Price-Whelan et al. 2006). Despite differences in regulatory elements, the pseudomonads described here all share the principle of QS-dependent control of phenazine biosynthesis (Mavrodi et al. 2006). Phenazines themselves may act as late QS signals in the sense that they regulate several dozens of genes that are not directly related to phenazine biosynthesis, during late growth phases (Dietrich et al. 2006).

AHLs regulate phenazine gene expression on roots (Wood et al. 1997) and can serve as interpopulation signals in the wheat rhizosphere (Pierson et al. 1998). AHL 'mimics' extracted from Medicago trunculata positively influence the expression of QS reporter constructs (Gao et al. 2003), but it is not known whether these compounds have an impact on biocontrol strains in the rhizosphere. By contrast, interference with AHL signalling has been observed in biocontrol bacteria: the phenazine-producer $P$. chlororaphis PCL1391 lost its ability to protect tomato against Fusarium wilt in the presence of AHL-degrading rhizobacteria (Molina et al. 2003) and unidentified signal molecules from a subpopulation of wheat rhizosphere-associated bacteria were found to affect phenazine gene expression negatively in $P$. aureofaciens 30-84 (Morello et al. 2004). Other interference may come from soil fungi which are a potential reservoir of QS 'quenchers'. For instance, penicillic acid and patulin are secondary metabolites of Penicillium spp. that inhibit the expression of QS reporter constructs (Rasmussen et al. 2005). Fusaric acid, a fungal metabolite, represses phenazine-1-carboxamide biosynthesis and $N$-hexanoyl-homoserine lactone production in P. chlororaphis PCL1391 (van Rij et al. 2005). Interestingly, salicylate, a plant defence signal, down-regulates pyocyanine formation by P. aeruginosa on plant roots (Prithiviraj et al. 2005). 


\section{Signals affecting biocontrol factor expression at a post-transcriptional level}

Small RNAs serve multiple regulatory purposes in bacteria, mostly at the level of mRNA stability and translation initiation. In many saprophytic bacteria, QS-dependent gene regulation can involve several small RNAs at critical checkpoints. Vibrio cholerae provides an excellent example: in this human pathogen the expression of the central virulence regulator HapR is determined by three converging QS pathways. All together, seven small RNAs are involved in these signal transduction pathways (Lenz et al. 2005). In one branch, the VarS/VarA two-component system positively controls the expression of three small RNAs termed CsrB, CsrC and CsrD. VarS is a sensor protein located in the cytoplasmic membrane and VarA is the cognate response regulator. Interaction of VarS with an external signal is assumed to result in autophosphorylation of VarS and in subsequent phosphotransfer to VarA. The three VarA-dependent small RNAs have a strong affinity for the small dimeric RNA-binding protein CsrA (Lenz et al. 2005), a translational regulator whose structure and function is conserved in a wide range of Gramnegative bacteria (Babitzke and Romeo 2007). Thus, at high cell densities, the small RNAs CsrB-CsrCCsrD sequester CsrA and this ultimately favours the expression of HapR, resulting in repression of virulence and biofilm genes (Bejerano-Sagie and Xavier 2007).

In fluorescent pseudomonads, as in other Gramnegative bacteria, the same (VarS/VarA-like) QS pathway is conserved although the output can vary. In P. fluorescens CHA0, this QS pathway has a major role in positively regulating biocontrol factor expression in various host-pathogen systems (Laville et al. 1992; Siddiqui et al. 2005). It is initiated by the GacS/ GacA two-component system, which is homologous to $\operatorname{VarS} / \mathrm{VarA}$, and it involves three functional homologs of CsrB-CsrC-CsrD, termed RsmX, RsmY and RsmZ, and two homologs of CsrA, termed RsmA and RsmE (Laville et al. 1992; Zuber et al. 2003; Reimmann et al. 2005; Kay et al. 2005) (Fig. 2a). The importance of the GacS/GacA pathway is supported by studies on gacS and gacA mutants of $P$. fluorescens BL915 and Pseudomonas sp. PCL1171 which have lost biocontrol properties (Ligon et al. 1999; van den Broek et al. 2003).
In strains of $P$. aeruginosa, the conserved $\mathrm{GacS} /$ GacA system directs the synthesis of two small RNAs, designated RsmY and RsmZ, which antagonize one CsrA homolog, named RsmA (Reimmann et al. 1997; Pessi et al. 2001; Heurlier et al. 2004; Kay et al. 2006) (Fig. 2b). In both P. aeruginosa PAO and $P$. fluorescens CHA0, the sequestration of the RNA-binding proteins (RsmA, and RsmE in the latter bacterium) by the small RNAs leads to translation of target mRNAs. Many target mRNAs specify enzymes for secondary metabolism or lytic exoenzymes. Typical target genes of $P$. fluorescens CHA0 are hcnA (for an HCN synthase subunit), phlA (for a subunit of the DAPG biosynthetic enzyme complex) and aprA (for exoprotease AprA) (Blumer et al. 1999; Zuber et al. 2003; Kay et al. 2005) (Fig. 2a). In $P$. aeruginosa, target genes include hcnA and the $p h z$ genes (Reimmann et al. 1997; Pessi et al. 2001) (Fig. 2b). Thus, there is in fact considerable overlap between virulence factors of $P$. aeruginosa and biocontrol traits of $P$. fluorescens. For instance, $\mathrm{HCN}$, phenazines and alkaline protease qualify for both attributes (Haas et al. 2004).

In $P$. aeruginosa, there are two sensors, RetS and LadS, in addition to GacS, all of which appear to determine the activity of GacA. RetS is an antagonist of GacA and might function as a phosphatase removing the phosphate group from phosphorylated GacA (Goodman et al. 2004; Laskowski and Kazmierczak 2006; Yahr and Wolfgang 2006). LadS, like GacS, appears to activate GacA (Ventre et al. 2006). Stimulation of $r \operatorname{sm} Y$ and $r s m Z$ transcription by phosphorylated GacA requires RsmA and probably further unknown factors (Fig. 2b). According to genomic sequence data, RetS and LadS also occur in $P$. fluorescens and $P$. putida strains, but the roles of these sensors remain to be determined. In strain CHA0, both RsmA and RsmE are involved in the expression of RsmX, RsmY and RsmZ (Fig. 2a).

In $P$. aeruginosa, the GacS/GacA system positively regulates the expression of the lasR, rhlR and rhlI genes and thereby stimulates the synthesis of $N$ butanoyl-homoserine lactone (Reimmann et al. 1997; Kay et al. 2006) (Fig. 2b). A similar positive effect of the GacS/GacA system on AHL synthesis is also found in biocontrol strains of $P$. chlororaphis, $P$. aureofaciens and P. putida (Chancey et al. 1999; Chin-A-Woeng et al. 2001b; Bertani and Venturi 2004; Han et al. 2006). In all fluorescent pseudomonads examined, 


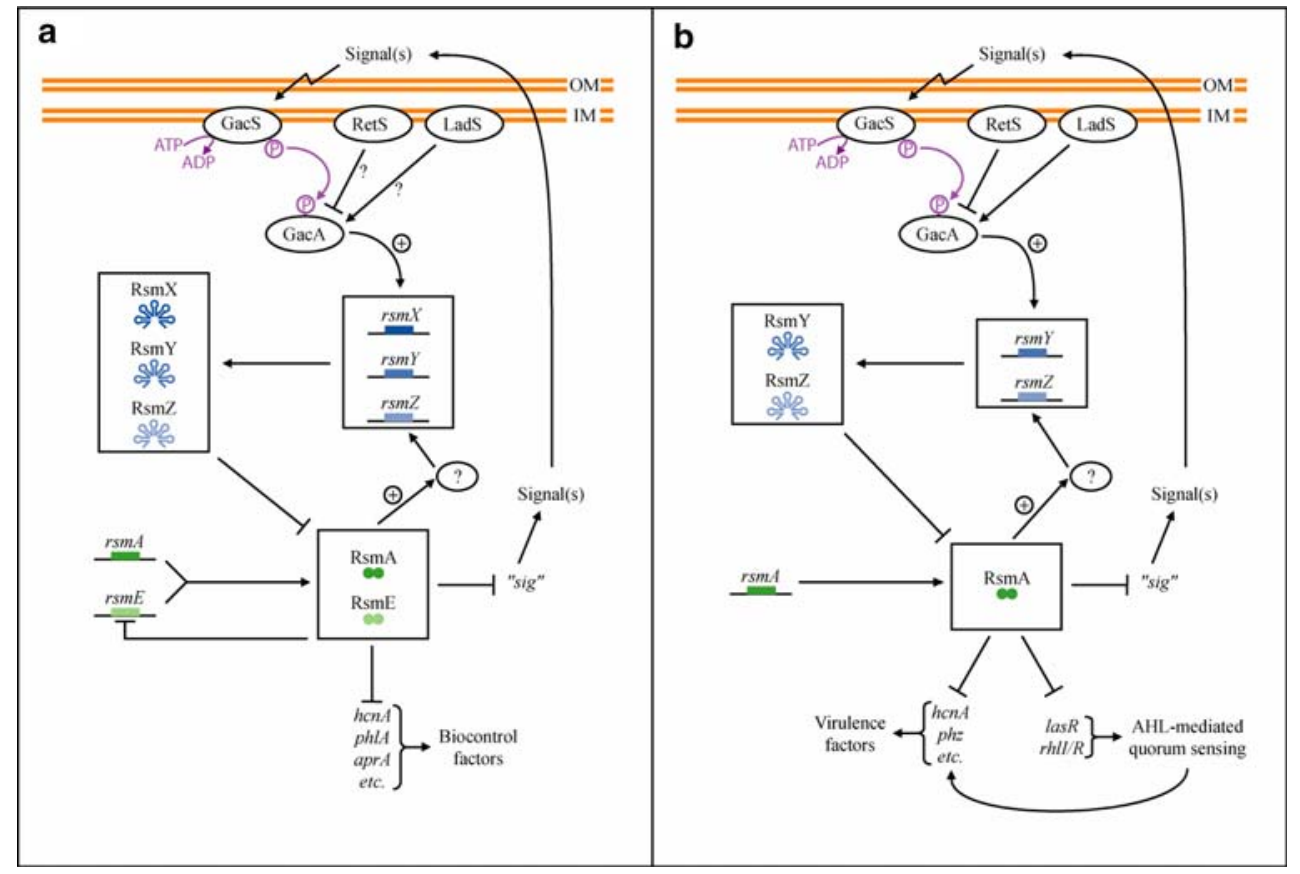

Fig. 2 Post-transcriptional signal transduction pathway downstream of the GacA response regulator in $P$. fluorescens $\mathrm{CHA} 0$ (a) and P. aeruginosa PAO1 (b). For a description of the

GacA function appears to favour the biofilm mode of growth, as opposed to planktonic life of single cells (Heeb and Haas 2001; Goodman et al. 2004; Ventre et al. 2006).

The signal molecules that activate the GacS/GacA cascade in bacteria have not been identified chemically nor are the signal biosynthetic genes known. The signals are unrelated to AHLs and some other well-known QS signals such as PQS, autoinducer 2 (AI-2; a furanosyl diester), or 3-hydroxy-palmitate methyl ester of Ralstonia spp. (Dubuis et al. 2006). In both $P$. fluorescens $\mathrm{CHA} 0$ and $P$. aeruginosa PAO, the signals activating the $\mathrm{GacS} / \mathrm{GacA}$ cascade are produced at high cell population densities and under positive GacA control. Mutants that are defective for GacA or the small RNAs (RsmX-RsmY-RsmZ and RsmY-RsmZ, respectively) synthesize $\leq 5 \%$ of signal, by comparison with the wild-type (Kay et al. 2005, 2006). Thus, the Gac signals have the characteristics of autoinducers (Fig. 2). In strain CHA0, thiamine is necessary for signal activity, biocontrol factor expression and suppression of $P$. ultimum on cress (Dubuis et al. 2006). Two tentative explanations can be offered for this effect at present. Either signal mechanisms, see text. OM, outer membrane; IM, inner membrane; sig, hypothetical signal biosynthetic genes. Violet arrows indicate phosphotransfer

biosynthesis requires relatively elevated levels of thiamine pyrophosphate as a cofactor such that a limiting thiamine supply will support central metabolism and growth, but not signal production, or thiamine could be a component of the Gac/Rsm signal transduction pathway. There is the intriguing possibility that thiamine triphosphate, a derivative of thiamine pyrophosphate, could be an intracellular signal. In Escherichia coli, amino acid starvation leads to transient accumulation of thiamine triphosphate (Lakaye et al. 2004).

AHLs are not the only QS signals that different species or genera of microorganisms can share to establish cross-talk (Riedel et al. 2001). The same has also been observed for AI-2 and for the Gac signals (Bassler et al. 1997; Dubuis and Haas 2007). A survey of beneficial and pathogenic plant-associated pseudomonads reveals that many species produce and release signal molecules activating the Gac/Rsm cascade in $P$. fluorescens and that this signal activity does not correlate with AHL production (Table 1). The bioassay used to detect Gac signals is illustrated in Fig. 3: The expression of the small RNA gene rsmZ and that of the biocontrol genes hcnA and phlA 
Table 1 Bacterial strains producing signal molecules activating the Gac/Rsm cascade in strain CHA0

\begin{tabular}{|c|c|c|c|c|c|}
\hline Species & Strain & Gac signal $^{\mathrm{a}}$ & AHLs & Comments & Reference or source \\
\hline Pseudomonas aeruginosa & PAO1 & ++ & $++^{\mathrm{b}, \mathrm{c}}$ & Pathogen, biocontrol ${ }^{\mathrm{e}, \mathrm{f}}$ & Holloway (1955) \\
\hline Pseudomonas corrugata & LMG 2172 & ++ & $+^{\mathrm{b}, \mathrm{c}}$ & Pathogen ${ }^{\mathrm{f}}$ & Sutra et al. (1997) \\
\hline \multirow[t]{7}{*}{ Pseudomonas fluorescens } & CHA0 & ++ & - & Biocontrol & Stutz et al. (1986) \\
\hline & $\mathrm{CM} 1^{\prime} \mathrm{A} 2$ & ++ & - & Biocontrol & Fuchs and Défago (1991) \\
\hline & F113 & ++ & $+^{\mathrm{d}}$ & Biocontrol & Fenton et al. (1992) \\
\hline & Pf-5 & ++ & - & Biocontrol & Paulsen et al. (2005) \\
\hline & PITR2 & ++ & - & Biocontrol & Harrison et al. (1993) \\
\hline & Q37-87 & ++ & $+^{\mathrm{b}}$ & Biocontrol & Keel et al. (1996) \\
\hline & Q65c-80 & ++ & - & Biocontrol & Harrison et al. (1993) \\
\hline Vibrio harveyi & BB120 & ++ & $+{ }^{\mathrm{d}}$ & Marine bacterium & Bassler et al. (1997) \\
\hline Vibrio natriegens & & ++ & - & Marine bacterium & A. Kukangara \\
\hline Pseudomonas aureofaciens & $30-84$ & + & $++^{\mathrm{b}, \mathrm{c}}$ & Biocontrol & Pierson et al. (1995) \\
\hline Pseudomonas caricapapayae & LMG 2152 & + & $++^{\mathrm{b}, \mathrm{c}}$ & Pathogen $^{\mathrm{f}}$ & Sutra et al. (1997) \\
\hline \multirow[t]{2}{*}{ Pseudomonas chlororaphis } & LMG 1245 & + & $+^{\mathrm{b}, \mathrm{c}}$ & Type strain & Sutra et al. (1997) \\
\hline & LMG 5004 & + & $+^{\mathrm{b}, \mathrm{c}}$ & Type strain & Sutra et al. (1997) \\
\hline \multirow[t]{9}{*}{ Pseudomonas fluorescens } & LMG 1794 & + & - & Type strain & Sutra et al. (1997) \\
\hline & $2-79$ & + & $+t^{\mathrm{b}, \mathrm{c}}$ & Biocontrol & Weller (1983) \\
\hline & M114 & + & - & Biocontrol & Fenton et al. (1992) \\
\hline & $\mathrm{P} 3$ & + & $+^{\mathrm{b}}$ & Soil bacterium & Sharifi-Tehrani et al. (1998) \\
\hline & $\mathrm{P} 12$ & + & $++^{\mathrm{b}, \mathrm{c}}$ & Biocontrol & Keel et al. (1996) \\
\hline & Pf0-1 & + & - & Soil bacterium & Compeau et al. (1988) \\
\hline & PILH1 & + & - & Biocontrol & Keel et al. (1996) \\
\hline & Q69c-80 & + & - & Biocontrol & Pierson and Weller (1994) \\
\hline & SBW25 & + & - & Biocontrol & Rainey and Bailey (1996) \\
\hline \multirow[t]{3}{*}{ Pseudomonas putida } & LMG 2257 & + & - & Type strain & Sutra et al. (1997) \\
\hline & $\mathrm{KD}$ & + & - & Biocontrol & Sharifi-Tehrani et al. (1998) \\
\hline & KT2440 & + & - & Soil bacterium & Franklin et al. (1981) \\
\hline Xanthomonas campestris & 8004 & + & - & Pathogen ${ }^{\mathrm{f}}$ & Turner et al. (1984) \\
\hline Escherichia coli & DH5 $\alpha$ & - & - & Laboratory strain & Sambrook and Russell (2001) \\
\hline Pseudomonas alcaligenes & Ps93 & - & - & Lipase producing strain & Gerritse et al. (1998) \\
\hline
\end{tabular}

a ++ , high signal activity, similar to that of P. fluorescens $\mathrm{CHA} 0 ;+$, intermediate signal activity, below that of $P$. fluorescens $\mathrm{CHA} 0 ;-$, no or insignificant signal activity detectable. Extracts containing the signals were obtained from 50-ml cultures as described before (Dubuis et al. 2006) and tested with $h c n A^{\prime}{ }^{\prime}{ }^{\prime} l a c Z$, rsmZ-lacZ and phlA' ${ }^{\prime}$ lacZ reporter constructs as shown in Fig. 4. Adapted from Dubuis (2005)

b +, Long chain AHLs detected by the reporter strain Agrobacterium tumefaciens NTL4/pZLR4 (Shaw et al. 1997)

c + , Short chain AHLs detected by the reporter strain Chromobacterium violaceum CV026 (McClean et al. 1997)

d AHLs produced by P. fluorescens F113 (N-(3-hydroxy-7-cis-tetradecenoyl)-homoserine lactone; Laue et al. 2000 and $V$. harveyi $N$-3-hydroxybutanoyl-homoserine lactone; Bassler et al. 1997) were not detected by the reporter strains A. tumefaciens NTL4/pZLR4 and C. violaceum $\mathrm{CV} 026$

e Pathogens for vertebrates

f Pathogens for plants

is stimulated about three-fold in P. fluorescens CHA0 by saturating amounts of the homologous signals. No stimulation is observed in a gacA mutant background
(Dubuis and Haas 2007). Signals extracted from culture supernatants of several biocontrol pseudomonads or from the pathogens $P$. aeruginosa, $P$. corrug- 

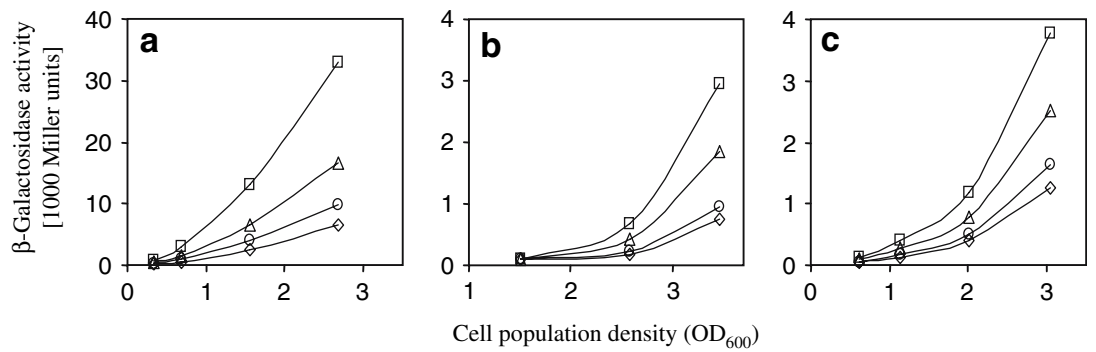

Fig. 3 Bioassay of signal activity. Dichloromethane-extracted supernatants from bacterial strains were tested with hcnA (a), rsmZ (b) and phlA (c) reporter strains as described elsewhere (Dubuis et al. 2006). B-Galactosidase measurements were carried out in triplicate using cells from the reporter strains P. fluorescens CHA0/pME6530 (hcnA'-'lacZ; a), CHA0/
pME6091 (rsmZ-lacZ; b) and CHA0/pME6702 (phlA'-'lacZ; c). $\diamond$, control without added extract; $\bigcirc$, plus extract from strain having weak or no signal activity; $\triangle$, plus extract from strain having intermediate signal activity; $\square$, plus extract from strain having strong, CHA0-like activity; $\mathrm{OD}_{600}$, optical density at $600 \mathrm{~nm}$. Adapted from Dubuis (2005)

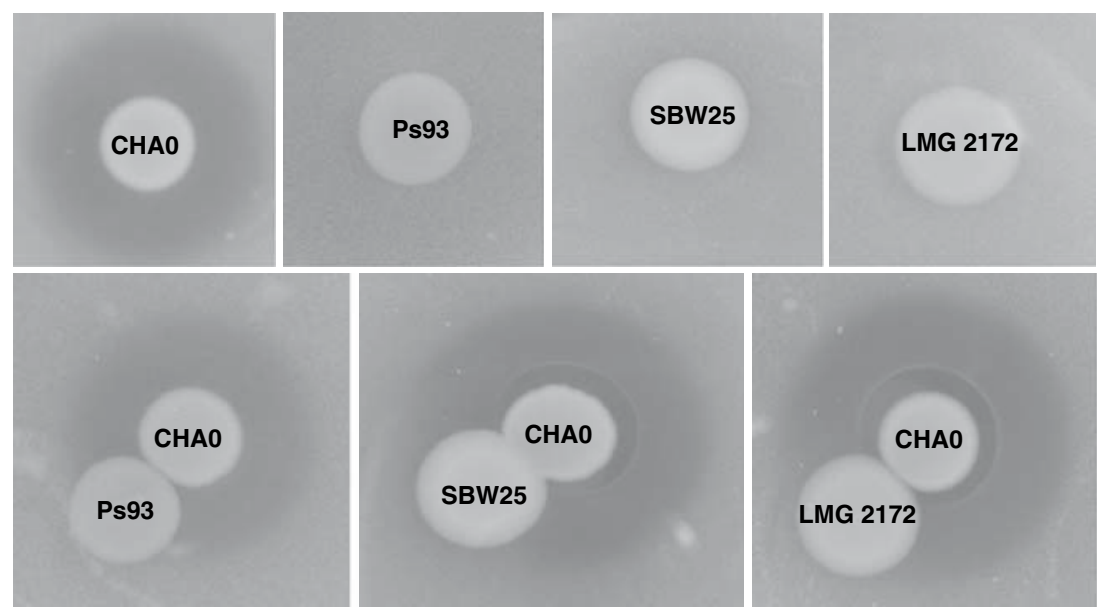

Fig. 4 Antibiotic production by $P$. fluorescens $\mathrm{CHA} 0$ in the presence of $P$. fluorescens SBW25, P. corrugata LMG 2172 or P. alcaligenes Ps93. Strains SBW25, LMG 2172 and Ps93 were inoculated by placing 5- $\mu$ l drops of overnight cultures

ata, P. caricapapayae and Xanthomonas campestris have similarly high or somewhat lower inducing activities (Table 1; Fig. 3). In this test, a rpfF mutant of $X$. campestris, which does not produce the diffusible signal factor (DSF; cis-11-methyl-dodecenoate), is still active. Interestingly, two Vibrio spp. have been found to have good signal activity, whereas $P$. alcaligenes and E. coli $\mathrm{DH} 5 \alpha$ are devoid of it (Dubuis and Haas 2007) (Table 1). Signal activity can be visualized as stimulation of antibiotic production in strain CHA0. When colonies of $P$. $f l u$ orescens SBW25 or P. corrugata LMG 2172 (both of which do not produce detectable antibiotic com- onto nutrient agar. After incubation at $30^{\circ} \mathrm{C}$ for $24 \mathrm{~h}, 5-\mu \mathrm{l}$ drops of a $\mathrm{CHA} 0$ culture were added and incubation was continued for $24 \mathrm{~h}$. An overlay with Bacillus subtilis revealed antibiotic production by growth inhibition zones

pounds) grow next to a colony of strain CHA0, greatly enhanced halos of growth inhibition of a sensitive indicator, Bacillus subtilis, can be observed. By contrast, the signal-negative strain Ps93 of $P$. alcaligenes has no effect on antibiotic production (Fig. 4). These experiments demonstrate the ability of various plant-associated bacteria to stimulate posttranscriptionally the expression of biocontrol factors (here: essentially DAPG) in P. fluorescens CHA0. Although inhibitory compounds would also be detected by the bioassay shown in Fig. 3, none of the microorganisms tested in Table 1 appears to have such activity. 


\section{Conclusions}

Biocontrol of root diseases by fluorescent pseudomonads is multifactorial; important mechanisms include antagonism between the biocontrol agents and the pathogens, degradation of virulence factors and induction of systemic resistance in the plant. Not surprisingly, both the biocontrol agents and the pathogens have developed defence mechanisms to minimize the impact of antagonism and some of these strategies have been shown to be active in the rhizosphere. Unlike predation, the biocontrol strategies that we have reviewed here work at a distance (of several micrometers) and rely on the emission or destruction of chemical signals. Root exudates critically influence the outcome, via signals that are mostly unknown and merit to be investigated. However, not all biocontrol interactions are of the antagonistic kind. Some previously unsuspected, positive interactions between rhizosphere bacteria stimulate the expression of biocontrol traits via the Gac/Rsm signal transduction pathway. This pathway operates essentially at a post-transcriptional level and in this respect differs from the better-characterized, AHL-dependent signal transduction pathways, whose outputs manifest themselves at the level of transcription. When activated, the Gac/Rsm cascade favours the biofilm mode of growth and the expression of multiple biocontrol factors in root-colonizing bacteria. Available reporter constructs facilitate the detection of activating signal molecules. In future research, it will be interesting to investigate which factors prevailing in the rhizosphere influence the activity of this signal transduction pathway as well as that of other key regulatory elements in plant-beneficial rhizobacteria.

Acknowledgements We gratefully acknowledge financial support from the Swiss National Science Foundation (projects 3100A0-100180 and 3100A0-105881) and from the State Secretariat for Education and Research (COST project C04.0201).

\section{References}

Abbas, A., McGuire, J. E., Crowley, D., Baysse, C., Dow, M., \& O'Gara, F. (2004). The putative permease PhlE of Pseudomonas fluorescens F113 has a role in 2,4-diacetylphloroglucinol resistance and in general stress tolerance. Microbiology, 150, 2443-2450.
Achkar, J., Xian, M., Zhao, H., \& Frost, J. W. (2005). Biosynthesis of phloroglucinol. Journal of the American Chemical Society, 127, 5332-5333.

Andersen, J. B., Koch, B., Nielsen, T. H., Sørensen, D., Hansen, M., Nybroe, O., Christophersen, C., Sørensen, J., Molin, S., \& Givskov, M. (2003). Surface motility in Pseudomonas sp. DSS73 is required for efficient biological containment of the root-pathogenic microfungi Rhizoctonia solani and Pythium ultimum. Microbiology, 149, 1147-1156.

Audenaert, K., Pattery, T., Cornelis, P., \& Höfte, M. (2002). Induction of systemic resistance to Botrytis cinerea in tomato by Pseudomonas aeruginosa 7NSK2: Role of salicylic acid, pyochelin, and pyocyanin. Molecular Plant-Microbe Interactions, 15, 1147-1156.

Babitzke, P., \& Romeo, T. (2007). CsrB sRNA family: Sequestration of RNA-binding regulatory proteins. Current Opinion in Microbiology, 10, 156-163.

Baehler, E., Bottiglieri, M., Péchy-Tarr, M., Maurhofer, M., \& Keel, C. (2005). Use of green fluorescent protein-based reporters to monitor balanced production of antifungal compounds in the biocontrol agent Pseudomonas fluorescens CHA0. Journal of Applied Microbiology, 99, 2438.

Baehler, E., de Werra, P., Wick, L. Y., Péchy-Tarr, M., Mathys, S., Maurhofer, M., \& Keel, C. (2006). Two novel MvaT-like global regulators control exoproduct formation and biocontrol activity in root-associated Pseudomonas fluorescens CHA0. Molecular Plant-Microbe Interactions, 19, 313-329.

Bais, H. P., Weir, T. L., Perry, L. G., Gilroy, S., \& Vivanco, J. M. (2006). The role of root exudates in rhizosphere interactions with plants and other organisms. Annual Review of Plant Biology, 57, 233-266.

Bangera, M. G., \& Thomashow, L. S. (1999). Identification and characterization of a gene cluster for synthesis of the polyketide antibiotic 2,4-diacetylphloroglucinol from Pseudomonas fluorescens Q2-87. Journal of Bacteriology, 181, 3155-3163.

Bassler, B. L., Greenberg, E. P., \& Stevens, A. M. (1997). Cross-species induction of luminescence in the quorumsensing bacterium Vibrio harveyi. Journal of Bacteriology, 179, 4043-4045.

Bejerano-Sagie, M., \& Xavier, K. B. (2007). The role of small RNAs in quorum sensing. Current Opinion in Microbiology, 10, 189-198.

Berg, G., Eberl, L., \& Hartmann, A. (2005). The rhizosphere as a reservoir for opportunistic human pathogenic bacteria. Environmental Microbiology, 7, 1673-1685.

Bertani, I., \& Venturi, V. (2004). Regulation of the $N$-acyl homoserine lactone-dependent quorum-sensing system in rhizosphere Pseudomonas putida WCS358 and cross-talk with the stationary-phase RpoS sigma factor and the global regulator GacA. Applied and Environmental Microbiology, 70, 5493-5502.

Blumer, C., \& Haas, D. (2000). Mechanism, regulation, and ecological role of bacterial cyanide biosynthesis. Archives of Microbiology, 173, 170-177.

Blumer, C., Heeb, S., Pessi, G., \& Haas, D. (1999). Global GacA-steered control of cyanide and exoprotease production in Pseudomonas fluorescens involves specific 
ribosome binding sites. Proceedings of the National Academy of Sciences USA, 96, 14073-14078.

Bottiglieri, M., \& Keel, C. (2006). Characterization of PhlG, a hydrolase that specifically degrades the antifungal compound 2,4-diacetylphloroglucinol in the biocontrol agent Pseudomonas fluorescens CHA0. Applied and Environmental Microbiology, 72, 418-427.

Brodhagen, M., Henkels, M. D., \& Loper, J. E. (2004). Positive autoregulation and signaling properties of pyoluteorin, an antibiotic produced by the biological control organism Pseudomonas fluorescens Pf-5. Applied and Environmental Microbiology, 70, 1758-1766.

Brodhagen, M., Paulsen, I., \& Loper, J. E. (2005). Reciprocal regulation of pyoluteorin production with membrane transporter gene expression in Pseudomonas fluorescens Pf-5. Applied and Environmental Microbiology, 71, 69006909.

Chancey, S. T., Wood, D. W., \& Pierson, L. S. 3rd. (1999). Two-component transcriptional regulation of $\mathrm{N}$-acyl-homoserine lactone production in Pseudomonas aureofaciens. Applied and Environmental Microbiology, 65, 22942299.

Chin-A-Woeng, T. F. C., Bloemberg, G. V., \& Lugtenberg, B. J. J. (2003). Phenazines and their role in biocontrol by Pseudomonas bacteria. New Phytologist, 157, 503-523.

Chin-A-Woeng, T. F. C., Thomas-Oates, J. E., Lugtenberg, B. J. J., \& Bloemberg, G. V. (2001a). Introduction of the phzH gene of Pseudomonas chlororaphis PCL1391 extends the range of biocontrol ability of phenazine-1-carboxylic acid-producing Pseudomonas spp. strains. Molecular Plant-Microbe Interactions, 14, 1006-1015.

Chin-A-Woeng, T. F. C., van den Broek, D., de Voer, G., van der Drift, K., Tuinman, S., Thomas-Oates, J. E., Lugtenberg, B. J. J., \& Bloemberg, G. V. (2001b). Phenazine-1carboxamide production in the biocontrol strain Pseudomonas chlororaphis PCL1391 is regulated by multiple factors secreted into the growth medium. Molecular Plant-Microbe Interactions, 14, 969-979.

Compant, S., Duffy, B., Nowak, J., Clement, C., \& Barka, E. A. (2005). Use of plant growth-promoting bacteria for biocontrol of plant diseases: Principles, mechanisms of action, and future prospects. Applied and Environmental Microbiology, 71, 4951-4959.

Compeau, G., Al-Achi, B. J., Platsouka, E., \& Levy, S. B. (1988). Survival of rifampin-resistant mutants of Pseudomonas fluorescens and Pseudomonas putida in soil systems. Applied and Environmental Microbiology, 54, 2432-2438.

de Souza, J. T., Arnould, C., Deulvot, C., Lemanceau, P., Gianinazzi-Pearson, V., \& Raaijmakers, J. M. (2003b). Effect of 2,4-diacetylphloroglucinol on Pythium: Cellular responses and variation in sensitivity among propagules and species. Phytopathology, 93, 966-975.

de Souza, J. T., Weller, D. M., \& Raaijmakers, J. M. (2003a). Frequency, diversity, and activity of 2,4-diacetylphloroglucinol-producing fluorescent Pseudomonas spp. in Dutch take-all decline soils. Phytopathology, 93, 54-63.

de Vleesschauwer, D., Cornelis, P., \& Höfte, M. (2006). Redox-active pyocyanin secreted by Pseudomonas aeruginosa 7HSK2 triggers systemic resistance to Magnaporthe grisea but enhances Rhizoctonia solani susceptibility in rice. Molecular Plant-Microbe Interactions, 19, 14061419.

de Werra, P., Huser, A., Baehler, E., Keel, C., \& Maurhofer, M. (2006). Using flow cytometry for in situ monitoring of antimicrobial compound production in the biocontrol bacterium Pseudomonas fluorescens CHA0. IOBC/WPRS Bulletin, 29, 117-121.

Delaney, S. M., Mavrodi, D. V., Bonsall, R. F., \& Thomashow, L. S. (2001). phzO, a gene for biosynthesis of 2-hydroxylated phenazine compounds in Pseudomonas aureofaciens 30-84. Journal of Bacteriology, 183, 318-327.

Delany, I., Sheehan, M. M., Fenton, A., Bardin, S., Aarons, S., \& O'Gara, F. (2000). Regulation of production of the antifungal metabolite 2,4-diacetylphloroglucinol in Pseudomonas fluorescens F113: Genetic analysis of phlF as a transcriptional repressor. Microbiology, 146, 537-543.

Dietrich, L. E. P., Price-Whelan, A., Petersen, A., Whiteley, M., \& Newman, D. K. (2006). The phenazine pyocyanin is a terminal signalling factor in the quorum sensing network of Pseudomonas aeruginosa. Molecular Microbiology, 61, 1308-1321.

Dubuis, C. (2005). Cell-cell communication in the biocontrol strain Pseudomonas fluorescens CHA0. PhD thesis, Switzerland, Département de microbiologie fondamentale, University of Lausanne.

Dubuis, C., \& Haas, D. (2007). Cross-species GacA-controlled induction of antibiosis in pseudomonads. Applied and Environmental Microbiology, 73, 650-654.

Dubuis, C., Rolli, J., Lutz, M., Défago, G., \& Haas, D. (2006). Thiamine-auxotrophic mutants of Pseudomonas fluorescens $\mathrm{CHA} 0$ are defective in cell-cell signaling and biocontrol factor expression. Applied and Environmental Microbiology, 72, 2606-2613.

Duffy, B., \& Défago, G. (1997). Zinc improves biocontrol of fusarium crown and root rot of tomato by Pseudomonas fluorescens and represses the production of pathogen metabolites inhibitory to bacterial antibiotic biosynthesis. Phytopathology, 87, 1250-1257.

Duffy, B., Keel, C., \& Défago, G. (2004). Potential role of pathogen signaling in multitrophic plant-microbe interactions involved in disease protection. Applied and Environmental Microbiology, 70, 1836-1842.

Duffy, B., Schouten, A., \& Raaijmakers, J. M. (2003). Pathogen self-defense: Mechanisms to counteract microbial antagonism. Annual Review of Phytopathology, 41, 501538.

Fenton, A. M., Stephens, P. M., Crowley, J., O'Callaghan, M., \& O'Gara, F. (1992). Exploitation of gene(s) involved in 2,4-diacetylphloroglucinol biosynthesis to confer a new biocontrol capability to a Pseudomonas strain. Applied and Environmental Microbiology, 58, 3873-3878.

Franklin, F. C., Bagdasarian, M., Bagdasarian, M. M., \& Timmis, K. N. (1981). Molecular and functional analysis of the TOL plasmid pWWO from Pseudomonas putida and cloning of genes for the entire regulated aromatic ring meta cleavage pathway. Proceedings of the National Academy of Sciences USA, 78, 7458-7462.

Fuchs, J., \& Défago, G. (1991). Protection of cucumber plants against black root rot caused by Phomopsis sclerotioides with rhizobacteria. In C. Keel, B. Koller, \& G. Défago (Eds.), Plant growth-promoting rhizobacteria-progress 
and prospects (pp. 51-56). Interlaken, Switzerland: IOBC/WPRS.

Fuqua, W. C., Winans, S. C., \& Greenberg, E. P. (1994). Quorum sensing in bacteria: The LuxR-LuxI family of cell density-responsive transcriptional regulators. Journal of Bacteriology, 176, 269-275.

Gantner, S., Schmid, M., Dürr, C., Schuhegger, R., Steidle, A., Hutzler, P., Langebartels, C., Eberl, L., Hartmann, A., \& Dazzo, F. B. (2006). In situ quantitation of the spatial scale of calling distances and population density-independent $\mathrm{N}$-acylhomoserine lactone-mediated communication by rhizobacteria colonized on plant roots. FEMS Microbiology Ecology, 56, 188-194.

Gao, M., Teplitski, M., Robinson, J. B., \& Bauer, W. D. (2003). Production of substances by Medicago trucatula that affect bacterial quorum sensing. Molecular PlantMicrobe Interactions, 16, 827-834.

Ge, Y., Huang, X., Wang, S., Zhang, X., \& Xu, Y. (2004). Phenazine-1-carboxylic acid is negatively regulated and pyoluteorin positively regulated by GacA in Pseudomonas sp. M18. FEMS Microbiology Letters, 237, 41-47.

Gerritse, G., Hommes, R. W., \& Quax, W. J. (1998). Development of a lipase fermentation process that uses a recombinant Pseudomonas alcaligenes strain. Applied and Environmental Microbiology, 64, 2644-2651.

Girard, G., Barends, S., Rigali, S., van Rij, E. T., Lugtenberg, B. J. J., \& Bloemberg, G. V. (2006). Pip, a novel activator of phenazine biosynthesis in Pseudomonas chlororaphis PCL1391. Journal of Bacteriology, 188, 8283-8293.

González, J. E., \& Keshavan, N. D. (2006). Messing with bacterial quorum sensing. Microbiology and Molecular Biology Reviews, 70, 859-875.

Goodman, A. L., Kulasekara, B., Rietsch, A., Boyd, D., Smith, R. S., \& Lory, S. (2004). A signaling network reciprocally regulates genes associated with acute infection and chronic persistence in Pseudomonas aeruginosa. Developmental Cell, 7, 745-754.

Haas, D., Blumer, C., \& Keel, C. (2000). Biocontrol ability of fluorescent pseudomonads genetically dissected: Importance of positive feedback regulation. Current Opinion in Biotechnology, 11, 290-297.

Haas, D., \& Défago, G. (2005). Biological control of soil-borne pathogens by fluorescent pseudomonads. Nature Reviews Microbiology, 3, 307-319.

Haas, D., \& Keel, C. (2003). Regulation of antibiotic production in root-colonizing Pseudomonas spp. and relevance for biological control of plant disease. Annual Review of Phytopathology, 41, 117-153.

Haas D., Reimmann C., \& Valverde, C. (2004). Common mechanisms in beneficial, deleterious host-microbe interactions. In L. Tikhonovich, B. Lugtenberg, \& N. Provorov (Eds.), Biology of plant-microbe interactions (Vol. 4, pp. 537-541). St. Paul, Minnesota, USA: International Society for Molecular Plant-Microbe Interactions.

Han, S. H., Lee, S. J., Moon, J. H., Park, K. H., Yang, K. Y., Cho, B. H., Kim, K. Y., Kim, Y. W., Lee, M. C., Anderson, A. J., \& Kim, Y. C. (2006). GacS-dependent production of 2R, 3R-butanediol by Pseudomonas chlororaphis $\mathrm{O} 6$ is a major determinant for eliciting systemic resistance against Erwinia carotovora but not against
Pseudomonas syringae pv. tabaci in tobacco. Molecular Plant-Microbe Interactions, 19, 924-930.

Harrison, L. A., Letendre, L., Kovacevich, P., Pierson, E., \& Weller, D. (1993). Purification of an antibiotic effective against Gaeumannomyces graminis var. tritici produced by a biocontrol agent, Pseudomonas aureofaciens. Soil Biology and Biochemistry, 25, 215-221.

Heeb, S., \& Haas, D. (2001). Regulatory roles of the GacS/ GacA two-component system in plant-associated and other Gram-negative bacteria. Molecular Plant-Microbe Interactions, 14, 1351-1363.

Hense, B. A., Kuttler, C., Müller, J., Rothballer, M., Hartmann, A., \& Kreft, J.-U. (2007). Does efficiency sensing unify diffusion and quorum sensing? Nature Reviews Microbiology, 5, 230-239.

Hernandez, M. E., Kappler, A., \& Newman, D. K. (2004). Phenazines and other redox-active antibioticx promote microbioal mineral reduction. Applied and Environmental Microbiology, 70, 921-928.

Heurlier, K., Williams, F., Heeb, S., Dormond, C., Pessi, G., Singer, D., Camara, M., Williams, P., \& Haas, D. (2004). Positive control of swarming, rhamnolipid synthesis, and lipase production by the posttranscriptional RsmA/RsmZ system in Pseudomonas aeruginosa PAO1. Journal of Bacteriology, 186, 2936-2945.

Hirsch, A. M., Bauer, W. D., Bird, D. M., Cullimore, J., Tyler, A. B., \& Yoderf, J. I. (2004). Molecular signals and receptors: Controlling rhizosphere interactions between plants and other organisms. Ecology, 84, 858-868.

Holloway, B. W. (1955). Genetic recombination in Pseudomonas aeruginosa. Journal of General Microbiology, 13, $572-581$.

Howell, C. R., \& Stipanovic, R. D. (1980). Suppression of Pythium ultimum-induced damping-off of cotton seedlings by Pseudomonas fluorescens and its antibiotic, pyoluteorin. Phytopathology, 70, 712-715.

Huang, Z., Bonsall, R. F., Mavrodi, D. V., Weller, D., \& Thomashow, L. S. (2003). Transformation of Pseudomonas fluorescens with genes for biosynthesis of phenazine1-carboxylic acid improves biocontrol of rhizoctonia root rot and in situ antibiotic production. FEMS Microbiology Ecology, 49, 243-251.

Huang, J. J., Petersen, A., Whiteley, M., \& Leadbetter, J. R. (2006a). Identification of QuiP, the product of gene PA1032, as the second acyl-homoserine lactone acylase of Pseudomonas aeruginosa PAO1. Applied and Environmental Microbiology, 72, 1190-1197.

Huang, X., Yan, A., Zhang, X., \& Xu, Y. (2006b). Identification and characterization of a putative $\mathrm{ABC}$ transporter PltHIJKN required for pyoluteorin production in Pseudomonas sp. M18. Gene, 376, 68-78.

Huang, X., Zhu, D., Ge, Y., Hu, H., Zhang, X., \& Xu, Y. (2004). Identification and characterization of pltZ, a gene involved in the repression of pyoluteorin biosynthesis in Pseudomonas sp. M18. FEMS Microbiology Letters, 232, 197-202.

Iavicoli, A., Boutet, E., Buchala, A., \& Métraux, J. P. (2003). Induced systemic resistance in Arabidopsis thaliana in response to root inoculation with Pseudomonas fluorescens CHA0. Molecular Plant-Microbe Interactions, 16, 851-858. 
Johansen, J. E., Binnerup, S. J., Lejbølle, K. B., Mascher, F., Sørensen, J., \& Keel, C. (2002). Impact of biocontrol strain Pseudomonas fluorescens CHA0 on rhizosphere bacteria isolated from barley (Hordeum vulgare L.) with special reference to Cytophaga-like bacteria. Journal of Applied Microbiology, 93, 1065-1074.

Jousset, A., Lara, E., Wall, L. G., \& Valverde, C. (2006). Secondary metabolites help biocontrol strain Pseudomonas fluorescens CHA0 to escape protozoan grazing. Applied and Environmental Microbiology, 72, 7083-7090.

Juhas, M., Eberl, L., \& Tümmler, B. (2005). Quorum sensing: The power of cooperation in the world of Pseudomonas. Environmental Microbiology, 7, 459-471.

Kaur, R., Macleod, J., Foley, W., \& Nayudu, M. (2006). Gluconic acid: An antifungal agent produced by Pseudomonas species in biological control of take-all. Phytochemistry, 67, 595-604.

Kay, E., Dubuis, C., \& Haas, D. (2005). Three small RNAs jointly ensure secondary metabolism and biocontrol in Pseudomonas fluorescens CHA0. Proceedings of the National Academy of Sciences USA, 102, 17136-17141.

Kay, E., Humair, B., Dénervaud, V., Riedel, K., Spahr, S., Eberl, L., Valverde, C., \& Haas, D. (2006). Two GacAdependent small RNAs modulate the quorum sensing response in Pseudomonas aeruginosa. Journal of Bacteriology, 188, 6026-6033.

Keel, C., Schnider, U., Maurhofer, M., Voisard, C., Laville, J., Burger, U., Wirthner, P., Haas, D., \& Défago, G. (1992). Suppression of root diseases by Pseudomonas fluorescens CHA0: Importance of the bacterial secondary metabolite 2,4-diacetylphloroglucinol. Molecular Plant-Microbe Interactions, 5, 4-13.

Keel, C., Weller, D. M., Natsch, A., Défago, G., Cook, R. J., \& Thomashow, L. S. (1996). Conservation of the 2,4-diacetylphloroglucinol biosynthesis locus among fluorescent Pseudomonas strains from diverse geographic locations. Applied and Environmental Microbiology, 62, 552-563.

Keel, C., Wirthner, P., Oberhänsli, T., Voisard, C., Burger, U., Haas, D., \& Défago, G. (1990). Pseudomonads as antagonists of plant pathogens in the rhizosphere: Role of the antibiotic 2,4-diacetylphloroglucinol in the suppression of black root rot of tobacco. Symbiosis, 9, 327-341.

Khan, S. R., Mavrodi, D. V., Jog, G. J., Suga, H., Thomashow, L. S., \& Farrand, S. K. (2005). Activation of the phz. operon of Pseudomonas fluorescens 2-79 requires the LuxR homolog PhzR, N-(3-OH-hexanoyl)-1-homoserine lactone produced by the LuxI homolog PhzI, and a cisacting phz box. Journal of Bacteriology, 187, 6517-6527.

Kraus, J., \& Loper, J. E. (1995). Characterization of a genomic region required for production of the antibiotic pyoluteorin by the biological control agent Pseudomonas fluorescens Pf-5. Applied and Environmental Microbiology, 61, 849-854.

Kuiper, I., Lagendijk, E. L., Pickford, R., Derrick, J. P., Lamers, G. E., Thomas-Oates, J. E., Lugtenberg, B. J. J., \& Bloemberg, G. V. (2004). Characterization of two Pseudomonas putida lipopeptide biosurfactants, putisolvin I and II, which inhibit biofilm formation and break down existing biofilms. Molecular Microbiology, 51, 97-113.

Lakaye, B., Wirtzfeld, B., Wins, P., Grisar, T., \& Bettendorff, L. (2004). Thiamine triphosphate, a new signal required for optimal growth of Escherichia coli during amino acid starvation. Journal of Biological Chemistry, 279, 1714217147.

Laskowski, M. A., \& Kazmierczak, B. I. (2006). Mutational analysis of RetS, an unusual sensor kinase-response regulator hybrid required for Pseudomonas aeruginosa virulence. Infection and Immunity, 74, 4462-4473.

Laue, B. E., Jiang, Y., Chhabra, S. R., Jacob, S., Stewart, G. S., Hardman, A., Downie, J. A., O'Gara, F., \& Williams, P. (2000). The biocontrol strain Pseudomonas fluorescens F113 produces the Rhizobium small bacteriocin, $N$-(3hydroxy-7-cis-tetradecenoyl)-homoserine lactone, via HdtS, a putative novel $N$-acylhomoserine lactone synthase. Microbiology, 146, 2469-2480.

Laville, J., Voisard, C., Keel, C., Maurhofer, M., Défago, G., \& Haas, D. (1992). Global control in Pseudomonas fluorescens mediating antibiotic synthesis and suppression of black root rot of tobacco. Proceedings of the National Academy of Sciences USA, 89, 1562-1566.

Lazdunski, A. M., Ventre, I., \& Sturgis, J. N. (2004). Regulatory circuits and communication in Gram-negative bacteria. Nature Reviews Microbiology, 2, 581-592.

Lenz, D. H., Miller, M. B., Zhu, J., Kulkarni, R. V., \& Bassler, B. L. (2005). CsrA and three redundant small RNAs regulate quorum sensing in Vibrio cholerae. Molecular Microbiology, 58, 1186-1202.

Ligon, J. M., Hill, D. S., Hammer, P. E., \& Torkewitz, N. R. (1999). Genetic modifications of Pseudomonas that enhance biological disease control. Acta Horticulturae, 504, 53-60.

Lugtenberg, B. J. J., \& Bloemberg, G. V. (2004). Life in the rhizosphere. In J. L. Ramos (Ed.), Pseudomonas: Genomics, life style and molecular archtecture (Vol. 1, pp. 403-430). New York, NY, USA: Kluwer Academic/Plenum Publishers.

Lugtenberg, B. J. J., Dekkers, L., \& Bloemberg, G. V. (2001). Molecular determinants of rhizosphere colonization by Pseudomonas. Annual Review of Phytopathology, 39, 461-490.

Lutz, M., Wenger, S., Maurhofer, M., Défago, G., \& Duffy, B. (2004). Signaling between bacterial and fungal biocontrol agents in a strain mixture. FEMS Microbiology Ecology, 48, 447-455.

Maurhofer, M., Baehler, E., Notz, R., Martinez, V., \& Keel, C. (2004). Cross talk between 2,4-diacetylphloroglucinolproducing biocontrol pseudomonads on wheat roots. Applied and Environmental Microbiology, 70, 1990-1998.

Maurhofer, M., Dubach, H., Haas, D., \& Défago, G. (2002). How soilborne fungal pathogens affect the production of 2,4-diacetylphloroglucinol in biocontrol strain Pseudomonas fluorescens CHA0. IOBC/WPRS Bulletin, 25, 102106.

Maurhofer, M., Keel, C., Haas, D., \& Défago, G. (1994). Pyoluteorin production by Pseudomonas fluorescens strain $\mathrm{CHA} 0$ is involved in the suppression of Pythium dampingoff of cress but not of cucumber. European Journal of Plant Pathology, 100, 221-232.

Maurhofer, M., Keel, C., Haas, D., \& Défago, G. (1995). Influence of plant species on disease suppression by Pseudomonas fluorescens strain CHA0 with enhanced antibiotic production. Plant Pathology, 44, 40-50. 
Maurhofer, M., Keel, C., Schnider, U., Voisard, C., Haas, D., \& Défago, G. (1992). Influence of enhanced antibiotic production in Pseudomonas fluorescens strain CHA0 on its disease suppressive capacity. Phytopathology, 82, 190195.

Mavrodi, D. V., Blankenfeldt, W., \& Thomashow, L. S. (2006). Phenazine compounds in fluorescent Pseudomonas spp. biosynthesis and regulation. Annual Review of Phytopathology, 44, 417-445.

Mavrodi, D. V., Bonsall, R. F., Delaney, S. M., Soule, M. J., Phillips, G., \& Thomashow, L. S. (2001). Functional analysis of genes for biosynthesis of pyocyanin and phenazine-1-carboxamide from Pseudomonas aeruginosa PAO1. Journal of Bacteriology, 183, 6454-6565.

Mavrodi, D. V., Ksenzenko, V. N., Bonsall, R. F., Cook, R. J., Boronin, A. M., \& Thomashow, L. S. (1998). A sevengene locus for synthesis is of phenazine-1-carboxylic acid by Pseudomonas fluorescens 2-79. Journal of Bacteriology, 180, 2541-2548.

Mazzola, M., Fujimoto, D. K., Thomashow, L. S., \& Cook, R. J. (1995). Variation in sensitivity of Gaeumannomyces graminis to antibiotics produced by fluorescent Pseudomonas spp. and effect on biological control of take-all of wheat. Applied and Environmental Microbiology, 61, 2554-2559.

McClean, K. H., Winson, M. K., Fish, L., Taylor, A., Chhabra, S. R., Camara, M., Daykin, M., Lamb, J. H., Swift, S., Bycroft, B. W., Stewart, G. S., \& Williams, P. (1997). Quorum sensing and Chromobacterium violaceum: Exploitation of violacein production and inhibition for the detection of $\mathrm{N}$-acylhomoserine lactones. Microbiology, 143, 3703-3711.

McDonald, M., Mavrodi, D. V., Thomashow, L. S., \& Floss, H. G. (2001). Phenazine biosynthesis in Pseudomonas fluorescens: Branchpoint from the primary shikimate biosynthetic pathway and role of phenazine-1,6-dicarboxylic acid. Journal of the American Chemical Society, 123, 9459-9460.

Moënne-Loccoz, Y., \& Défago, G. (2004). Life as a biocontrol pseudomonad. In J. L. Ramos (Ed.), Pseudomonas: Genomics, life style and molecular archtecture (Vol. 1, pp. 457-476). New York, NY, USA: Kluwer Academic/Plenum Publishers.

Molina, L., Constantinescu, F., Michel, L., Reimmann, C., Duffy, B., \& Défago, G. (2003). Degradation of pathogen quorum-sensing molecules by soil bacteria: A preventive and curative biological control mechanism. FEMS Microbiology Ecology, 45, 71-81.

Morello, J. E., Pierson, E. A., \& Pierson, L. S. 3rd. (2004). Negative cross-communication among wheat rhizosphere bacteria: Effect on antibiotic production by the biological control bacterium Pseudomonas aureofaciens 30-84. Applied and Environmental Microbiology, 70, 3103-3109.

Nealson, K. H. (1977). Autoinduction of bacterial luciferase. Occurrence, mechanism and significance. Archives of Microbiology, 112, 73-79.

Notz, R., Maurhofer, M., Dubach, H., Haas, D., \& Défago, G. (2002). Fusaric acid-producing strains of Fusarium oxysporum alter 2,4-diacetylphloroglucinol biosynthetic gene expression in Pseudomonas fluorescens $\mathrm{CHA} 0$ in vitro and in the rhizosphere of wheat. Applied and Environmental Microbiology, 68, 2229-2235.

Notz, R., Maurhofer, M., Schnider-Keel, U., Duffy, B., Haas, D., \& Défago, G. (2001). Biotic factors affecting expression of the 2,4-diacetylphloroglucinol biosynthesis gene phlA in Pseudomonas fluorescens biocontrol strain CHA0 in the rhizosphere. Phytopathology, 91, 873-881.

Nowak-Thompson, B., Chaney, N., Wing, J. S., Gould, S. J., \& Loper, J. E. (1999). Characterization of the pyoluteorin biosynthetic gene cluster of Pseudomonas fluorescens Pf5. Journal of Bacteriology, 181, 2166-2174.

Parsons, J. F., Greenhagen, B. T., Shi, K., Calabrese, K., Robinson, H., \& Ladner, J. E. (2007). Structural and functional analysis of the pyocyanin biosynthetic protein PhzM from Pseudomonas aeruginosa. Biochemistry, 46, 1821-1828.

Paulsen, I. T., Press, C. M., Ravel, J., Kobayashi, D. Y., Myers, G. S., Mavrodi, D. V., DeBoy, R. T., Seshadri, R., Ren, Q., Madupu, R., Dodson, R. J., Durkin, A. S., Brinkac, L. M., Daugherty, S. C., Sullivan, S. A., Rosovitz, M. J., Gwinn, M. L., Zhou, L., Schneider, D. J., Cartinhour, S. W., Nelson, W. C., Weidman, J., Watkins, K., Tran, K., Khouri, H., Pierson, E. A., Pierson, L. S. 3rd, Thomashow, L. S., \& Loper, J. E. (2005). Complete genome sequence of the plant commensal Pseudomonas fluorescens Pf-5. Nature Biotechnology, 23, 873-878.

Péchy-Tarr, M., Bottiglieri, M., Mathys, S., Bang-Lejbølle, K., Schnider-Keel, U., Maurhofer, M., \& Keel, C. (2005). RpoN (sigma ${ }^{54}$ ) controls production of antifungal compounds and biocontrol activity in Pseudomonas fluorescens CHA0. Molecular Plant-Microbe Interactions, 18, 260-272.

Pessi, G., Williams, F., Hindle, Z., Heurlier, K., Holden, M. T., Camara, M., Haas, D., \& Williams, P. (2001). The global posttranscriptional regulator RsmA modulates production of virulence determinants and $\mathrm{N}$-acylhomoserine lactones in Pseudomonas aeruginosa. Journal of Bacteriology, 183, 6676-6683.

Phillips, D. A., Fox, T. C., King, M. D., Bhuvaneswari, T. V., \& Teuber, L. R. (2004). Microbial products trigger amino acid exudation from plant roots. Plant Physiology, 136, 2887-2894.

Phillips, D. A., \& Kapulnik, Y. (1995). Plant isoflavonoids, pathogens and symbionts. Trends in Microbiology, 3, 5864.

Pierson, L. S. 3rd, Gaffney, T., Lam, S., \& Gong, F. (1995). Molecular analysis of genes encoding phenazine biosynthesis in the biological control bacterium. Pseudomonas aureofaciens 30-84. FEMS Microbiology Letters, 134, 299-307.

Pierson, E. A., \& Weller, D. M. (1994). Use of mixtures of fluorescent pseudomonads to suppress take-all and improve the growth of wheat. Phytopathology, 84, 940-947.

Pierson, L. S. 3rd, Wood, D. W., \& Pierson, E. A. (1998). Homoserine lactone-mediated gene regulation in plantassociated bacteria. Annual Review of Phytopathology, 36, 207-225.

Price-Whelan, A., Dietrich, L. E., \& Newman, D. K. (2006). Rethinking 'secondary' metabolism: Physiological roles for phenazine antibiotics. Nature Chemical Biology, 2, 71-78. 
Prithiviraj, B., Bais, H. P., Weir, T., Suresh, B., Najarro, E. H., Dayakar, B. V., Schweizer, H. P., \& Vivanco, J. M. (2005). Down regulation of virulence factors of Pseudomonas aeruginosa by salicylic acid attenuates its virulence on Arabidopsis thaliana and Caenorhabditis elegans. Infection and Immunity, 73, 5319-5328.

Quay, S. C., Friedman, S. B., \& Eisenberg, R. C. (1972). Gluconate regulation of glucose catabolism in Pseudomonas fluorescens. Journal of Bacteriology, 112, 291298.

Raaijmakers, J. M., de Bruijn, I., \& de Kock, M. J. D. (2006). Cyclic lipopeptide production by plant-associated $\mathrm{Pseu}$ domonas spp.: Diversity, activity, biosynthesis, and regulation. Molecular Plant-Microbe Interactions, 19, 699710 .

Raaijmakers, J. M., Vlami, M., \& de Souza, J. T. (2002). Antibiotic production by bacterial biocontrol agents. Antonie van Leeuwenhoek, 81, 537-547.

Rainey, P. B., \& Bailey, M. J. (1996). Physical and genetic map of the Pseudomonas fluorescens SBW25 chromosome. Molecular Microbiology, 19, 521-533.

Ramette, A., Moënne-Loccoz, Y., \& Défago, G. (2003). Prevalence of fluorescent pseudomonads producing antifungal phloroglucinols and/or hydrogen cyanide in soils naturally suppressive or conducive to tobacco black root rot. FEMS Microbiology Ecology, 44, 35-43.

Rasmussen, T. B., Skindersoe, M. E., Bjarnsholt, T., Phipps, R. K., Christensen, K. B., Jensen, P. O., Andersen, J. B., Koch, B., Larsen, T. O., Hentzer, M., Eberl, L., Høiby, N., \& Givskov, M. (2005). Identity and effects of quorumsensing inhibitors produced by Penicillium species. Microbiology, 151, 1325-1340.

Reimmann, C., Beyeler, M., Latifi, A., Winteler, H., Foglino, M., Lazdunski, A., \& Haas, D. (1997). The global activator GacA of Pseudomonas aeruginosa PAO1 positively controls the production of the autoinducer $\mathrm{N}$-butyryl-homoserine lactone and the formation of the virulence factors pyocyanin, cyanide, and lipase. Molecular Microbiology, 24, 309-319.

Reimmann, C., Valverde, C., Kay, E., \& Haas, D. (2005). Posttranscriptional repression of $\mathrm{GacS} / \mathrm{GacA}$-controlled genes by the RNA-binding protein RsmE acting together with RsmA in the biocontrol strain Pseudomonas fluorescens CHA0. Journal of Bacteriology, 187, 276-285.

Rezzonico, F., Zala, M., Keel, C., Duffy, B., Moënne-Loccoz, Y. \& Défago, G. (2007). Is the ability of biocontrol fluorescent pseudomonads to produce the antifungal metabolite 2,4-diacetylphloroglucinol really synonymous with higher plant protection? New Phytologist, 173, 861-872.

Riedel, K., Hentzer, M., Geisenberger, O., Huber, B., Steidle, A., Wu, H., Hoiby, N., Givskov, M., Molin, S., \& Eberl, L. (2001). N-Acylhomoserine-lactone-mediated communication between Pseudomonas aeruginosa and Burkholderia cepacia in mixed biofilms. Microbiology, 147, 3249-3262.

Sambrook, J., \& Russell, D. W. (2001). Molecular cloning: A laboratory manual (3rd ed.). Cold Spring Harbor, N.Y.: Cold Spring Harbor Laboratory Press.

Sarniguet, A., Kraus, J., Henkels, M. D., Muehlchen, A. M. \& Loper, J. E. (1995). The sigma factor sigma s affects antibiotic production and biological control activity of
Pseudomonas fluorescens Pf-5. Proceedings of the National Academy of Sciences USA, 92, 12255-12259.

Schmidli-Sacherer, P., Keel, C., \& Défago, G. (1997). The global regulator GacA of Pseudomonas fluorescens CHA0 is required for suppression of root diseases in dicotyledons but not in Gramineae. Plant Pathology, 46, 80-90.

Schnider, U., Keel, C., Blumer, C., Troxler, J., Défago, G., \& Haas, D. (1995). Amplification of the housekeeping sigma factor in Pseudomonas fluorescens CHA0 enhances antibiotic production and improves biocontrol abilities. Journal of Bacteriology, 177, 5387-5392.

Schnider-Keel, U., Seematter, A., Maurhofer, M., Blumer, C., Duffy, B., Gigot-Bonnefoy, C., Reimmann, C., Notz, R., Défago, G., Haas, D., \& Keel, C. (2000). Autoinduction of 2,4-diacetylphloroglucinol biosynthesis in the biocontrol agent Pseudomonas fluorescens $\mathrm{CHA} 0$ and repression by the bacterial metabolites salicylate and pyoluteorin. Journal of Bacteriology, 182, 1215-1225.

Schouten, A., van den Berg, G., Edel-Hermann, V., Steinberg, C., Gautheron, N., Alabouvette, C., de Vos, C. H., Lemanceau, P., \& Raaijmakers, J. M. (2004). Defense responses of Fusarium oxysporum to 2,4-diacetylphloroglucinol, a broad-spectrum antibiotic produced by Pseudomonas fluorescens. Molecular Plant-Microbe Interactions, 17, 1201-1211.

Sharifi-Tehrani, A., Zala, M., Natsch, A., Moënne-Loccoz, Y., \& Défago, G. (1998). Biocontrol of soilborne fungal plant diseases by 2,4-diacetylphloroglucinol-producing fluorescent Pseudomonas with different restriction profiles of amplified 16S rDNA. European Journal of Plant Pathology, 104, 631-643.

Shaw, P. D., Ping, G., Daly, S. L., Cha, C., Cronan, J. E. Jr., Rinehart, K. L., \& Farrand, S. K. (1997). Detecting and characterizing $\mathrm{N}$-acyl-homoserine lactone signal molecules by thin-layer chromatography. Proceedings of the National Academy of Sciences USA, 94, 6036-6041.

Siddiqui, I. A., Haas, D., \& Heeb, S. (2005). Extracellular protease of Pseudomonas fluorescens CHA0, a biocontrol factor with activity against the root-knot nematode Meloidogyne incognita. Applied and Environmental Microbiology, 71, 5646-5649.

Siqueira, J. O., Nair, M. G., Hammerschmidt, R., \& Safir, G. R. (1991). Significance of phenolic compounds in plant-soilmicrobial systems. Critical Reviews in Plant Sciences, 10, 63-121.

Somers, E., Vanderleyden, J., \& Srinivasan, M. (2004). Rhizosphere bacterial signalling: A love parade beneath our feet. Critical Reviews in Microbiology, 30, 205-240.

Steidle, A., Sigl, K., Schuhegger, R., Ihring, A., Schmid, M., Gantner, S., Stoffels, M., Riedel, K., Givskov, M., Hartmann, A., Langebartels, C., \& Eberl, L. (2001). Visualization of $\mathrm{N}$-acylhomoserine lactone-mediated cell-cell communication between bacteria colonizing the tomato rhizosphere. Applied and Environmental Microbiology, 67, 5761-5770.

Stutz, E. W., Défago, G., \& Kern, H. (1986). Naturally occurring fluorescent pseudomonads involved in suppression of black root rot of tobacco. Phytopathology, 76, 181-185.

Sutra, L., Siverio, F., Lopez, M. M., Hunault, G., Bollet, C., \& Gardan, L. (1997). Taxonomy of Pseudomonas strains 
isolated from tomato pith necrosis: Amended description of Pseudomonas corrugata and proposal of three unnamed fluorescent Pseudomonas genomospecies. International Journal of Systematic Bacteriology, 47, 1020-1033.

Thomashow, L. S., \& Weller, D. M. (1988). Role of a phenazine antibiotic from Pseudomonas fluorescens in biological control of Gaeumannomyces graminis var. tritici. Journal of Bacteriology, 170, 3499-3508.

Troxler, J., Azelvandre, P., Zala, M., Défago, G., \& Haas, D. (1997). Conjugative transfer of chromosomal genes between fluorescent pseudomonads in the rhizosphere of wheat. Applied and Environmental Microbiology, 63, 213-219.

Turner, P., Barber, C., \& Daniels, M. (1984). Behavior of the transposon Tn5 and Tn7 in Xanthomonas campestris pv. campestris. Molecular and General Genetics, 195, 101-107.

van den Broek, D., Chin-A-Woeng, T. F. C., Eijkemans, K., Mulders, I. H. M., Bloemberg, G. V., \& Lugtenberg, B. J. J. (2003). Biocontrol traits of Pseudomonas spp. are regulated by phase variation. Molecular Plant-Microbe Interactions, 16, 1003-1012.

van Loon, L. C., Bakker, P. A. H. M., \& Pieterse, C. M. J. (1998). Systemic resistance induced by rhizosphere bacteria. Annual Review of Phytopathology, 36, 453-483.

van Rij, E. T., Girard, G., Lugtenberg, B. J. J., \& Bloemberg, G. V. (2005). Influence of fusaric acid on phenazine-1carboxamide synthesis and gene expression of Pseudomonas chlororaphis strain PCL1391. Microbiology, 151, 2805-2814.

Ventre, I., Goodman, A. L., Vallet-Gely, I., Vasseur, P., Soscia, C., Molin, S., Bleves, S., Lazdunski, A., Lory, S., Filloux, A. (2006). Multiple sensors control reciprocal expression of Pseudomonas aeruginosa regulatory RNA and virulence genes. Proceedings of the National Academy of Sciences USA, 103, 171-176.

Wang, C., Zhang, H. B., Wang, L. H., \& Zhang, L. H. (2006). Succinic semialdehyde couples stress response to quorumsensing signal decay in Agrobacterium tumefaciens. Molecular Microbiology, 62, 45-56.

Wei, H. L., \& Zhang, L. Q. (2006). Quorum-sensing system influences root colonization and biological control ability in Pseudomonas fluorescens 2P24. Antonie van Leeuwenhoek, 267-280, 1-14.

Weller, D. M. (1983). Colonization of wheat roots by a fluorescent pseudomonad suppressive to take-all. Phytopathology, 73, 1548-1553.

Weller, D. M., Landa, B. B., Mavrodi, O. V., Schroeder, K. L., De La Fuente, L., Blouin Bankhead, S., Allende Molar,
R., Bonsall, R. F., Mavrodi, D. V., \& Thomashow, L. S. (2007). Role of 2,4-diacetylphloroglucinol-producing fluorescent Pseudomonas spp. in the defense of plant roots. Plant Biology, 9, 4-20.

Weller, D. M., Raaijmakers, J. M., Gardener, B. B., \& Thomashow, L. S. (2002). Microbial populations responsible for specific soil suppressiveness to plant pathogens. Annual Review of Phytopathology, 40, 309-348.

Whistler, C. A., \& Pierson, L. S. 3rd. (2003). Repression of phenazine antibiotic production in Pseudomonas aureofaciens strain 30-84 by RpeA. Journal of Bacteriology, 185, 3718-3725.

Whistler, C. A., Stockwell, V. O., \& Loper, J. E. (2000). Lon protease influences antibiotic production and UV tolerance of Pseudomonas fluorescens Pf-5. Applied and Environmental Microbiology, 66, 2718-2725.

Winzer, K., Hardie, K. R., \& Williams, P. (2002). Bacterial cell-to-cell communication: Sorry, can't talk now-gone to lunch! Current Opinion in Microbiology, 5, 216-222.

Wood, D. W., Gong, F., Daykin, M., Williams, P., \& Pierson, L. S. (1997). N-Acyl-homoserine lactone-mediated regulation of phenazine gene expression by Pseudomonas aureofaciens 30-84 in the wheat rhizosphere. Journal of Bacteriology, 179, 7663-7670.

Wood, D. W., \& Pierson, L. S. (1996). The phzI gene of Pseudomonas aureofaciens 30-84 is responsible for the production of a diffusible signal required for phenazine antibiotic production. Gene, 168, 49-53.

Xavier, K. B., \& Bassler, B. L. (2005). Interference with AI-2mediated bacterial cell-cell communication. Nature, 437, 750-753.

Yahr, T. L., \& Wolfgang, M. C. (2006). Transcriptional regulation of the Pseudomonas aeruginosa type III secretion system. Molecular Microbiology, 62, 631-640.

Zha, W., Rubin-Pitel, S. B., \& Zhao, H. (2006). Characterization of the substrate specificity of PhlD, a type III polyketide synthase from Pseudomonas fluorescens. Journal of Biological Chemistry, 281, 32036-32047.

Zhang, L. H., \& Dong, Y. H. (2004). Quorum sensing and signal interference: Diverse implications. Molecular Microbiology, 53, 1563-1571.

Zuber, S., Carruthers, F., Keel, C., Mattart, A., Blumer, C., Pessi, G., Gigot-Bonnefoy, C., Schnider-Keel, U., Heeb, S., Reimmann, C., \& Haas, D. (2003). GacS sensor domains pertinent to the regulation of exoproduct formation and to the biocontrol potential of Pseudomonas fluorescens CHA0. Molecular Plant-Microbe Interactions, 16, 634-644. 